\title{
Preparation of isomaltooligosaccharides using puffed rice flour and evaluation of physicochemical properties
}

\author{
Eun Byeol Lee, Ha-Yun Kim, Gui Jeong Han, Bo-Ram Park* \\ Department of Agrofood Resources, National Institute of Agricultural Science, Rural Development Administration, \\ Jeonju 54875, Korea
}

\section{팽화미분 이용 이소말토올리고당 제조 및 이화학적 품질특성}

\author{
이은별 · 김하윤 · 한귀정 · 박보람* \\ 농촌진흥청 국립농업과학원 농식품자원부
}

\begin{abstract}
Isomaltooligosaccharides were prepared from puffed rice flour by a One-step processing method under different conditions, and their physicochemical properties were evaluated. Sample was prepared by allowing puffed rice flour to pass through a 50 mesh standard sieve and segregated into experimental groups (PR15-60, PR20-60, PR15-65, and PR20-65) according to the substrate concentrations $(15 \%, 20 \% \mathrm{w} / \mathrm{v})$ and reaction temperatures $\left(60^{\circ} \mathrm{C}, 65^{\circ} \mathrm{C}\right)$. Enzyme reaction of puffed rice flour and water mixture was performed for $0,1,6,24$, and $48 \mathrm{~h}$ using commercial enzymes (Maltogenic amylase, Promozyme D2 and Transglucosidase; amount: $0.5 \%$ (w/v) to obtain the corresponding isomaltooligosaccharides. The reducing sugar content, dextrose equivalent, and total soluble solids of the reactants increased with increasing reaction time. The carbohydrate composition and amount of isomaltooligosaccharides with degree of polymerization (DP) 2 to DP 7 in the rice flour were examined by HPLC with an evaporative light scattering detector. Because of the high carbohydrate composition, the PR20-65 group showed the highest isomaltooligosaccharide content after $6 \mathrm{~h}$ of reation $(138.47 \mathrm{mg} / \mathrm{mL})$. After $24 \mathrm{~h}$ of reaction, the amount of isomaltooligosaccharides (DP2-DP7) and the isomaltooligosaccharides/total carbohydrate ratio in this group were $135.00 \mathrm{mg} / \mathrm{mL}$ and $68.04 \%$, respectively.
\end{abstract}

Key words : puffed rice, isomaltooligosaccharides, rice flour

\section{서 론}

이소말토올리고당(isomaltooligosaccharide, IMO)은 포 도당 분자가 1 개 이상의 분지결합(a-1,6)을 이루어 중합도 (DP) 2-9를 형성하는 당류를 총칭하는 것으로 대표적으로 isomaltose, panose, isomatotriose 등으로 구성되어 있으며 $(1,2)$, 청주(3), 간장(4), 식혜(5) 등 발효식품에도 소량 존재 하는 것으로 밝혀졌다. 이소말토올리고당의 생리학적 기능

*Corresponding author. E-mail : bboram27@korea.kr Phone : 82-63-238-3642, Fax : 82-63-238-3843

Received 20 December 2017; Revised 3 April 2018; Accepted 11 April 2018.

Copyright (c) The Korean Society of Food Preservation. All rights reserved.
은 대표적으로 장내 Bifidobacteria를 증식시켜 정장작용을 촉진하는 prebiotics 특성과 충치를 예방하는 효과가 알려져 있으며(6-8) 비피더스균에 의해 장내 $\mathrm{pH}$ 저하로 인한 유해 균의 성장억제(9), 면역력 강화(10) 체내 콜레스테롤 개선 (11) 등 다양한 효능 연구가 진행되어 왔다. 이소말토올리고 당의 감미도는 설탕의 $1 / 2$ 수준으로 순한 단맛을 가지며, 감칠맛을 특징으로 하여 양질의 감미료로 사용 가능하고 (1), 포도당 분자 간 a-1,6 결합으로 인해 노화방지 효과뿐만 아니라 열 안정성 및 산에 대한 안정성도 커서(12) 식품에 광범위하게 응용이 가능하다.

이러한 이소말토올리고당의 제조는 전분함량이 높은 옥 수수, 감자, 타피오카, 쌀 등을 원료로 하여 일정량의 물을 배합 후 효소 처리, 여과, 정제, 농축 공정을 거쳐 제품화가 이루어지는데 효소 처리과정에서 액화, 당화, 전이효소가 
각각 투입된다. 제조 첫 번째 단계에서 투입하는 액화 효소 는 전분질 원료가 물과 열에 의해 호화되고 아밀로오스와 아밀로펙틴이 교질화되어 나타나는 고점도 상태를 덱스트 린 단위로 분해하여 점도를 낮추기 위하여 투입하는 것이 다. 따라서 고온에서도 활성을 잃지 않는 고온용 액화효소 (미생물 유래)를 사용하게 되며, 이로 인해 전분의 $a-1,4$ 결합을 무작위로 가수분해하여 dextrin과 각종 올리고당을 생성하게 된다(13). 당화 효소는 아밀로펙틴의 분지결합(a -1,6)을 절단하는 단계로 주로 전분의 비환원 말단으로부터 a-1,4 배당결합을 분해하는 이 효소의 작용으로 인해 덱스 트린 단위의 전분이 더 작은 단위로 쪼개지며 환원당 및 $\mathrm{DE}$ (dextrose equivalent)값이 증가하게 되고 이 반응의 온도 범위는 $60^{\circ} \mathrm{C}$ 정도이다(14). 마지막으로 전이효소는 Asperguillus niger 유래의 TransGlucosidase(TG)를 투입, 당 화액(주로 포도당, maltose, maltotriose)을 기질로 가수분해 하여 a-1,6 결합이 생성되는 전이과정을 통해 isomaltose, isomaltotriose 등을 주성분으로 하는 이소말토올리고당을 생성하게 된다 $(1,15)$. 올리고당은 이와 같이 복잡한 단계를 거쳐 만들어지는 탓에 전화효소로 단일 단계 당화 반응을 촉매 함으로써 이소말토올리고당 생산의 시간 및 에너지를 감소할 수 있다고 발표된 대한민국 공개특허 제 2012-0019391호와 같이 이의 단순화를 위한 방법들이 모색 되고 있다.

한편, 국내 쌀 소비량은 식생활의 변화와 생활수준 향상 으로 인해 꾸준히 감소하는 추세이며(16) 우리나라 쌀 재고 와 함께 WTO 무역협정에 따라 2004년부터 의무적인 쌀 수입으로(17) 재고량이 급속히 증가되면서 장기보관에 따 른 관리비용 부담 및 품질 저하문제(18) 등으로 쌀을 이용한 식품 소재화 연구를 통한 소비 촉진이 필요한 실정이다.

팽화미는 건조된 쌀을 압력솥에 넣고 가열하여 고온·고 압 상태를 만들어준 뒤, 순간적으로 상압으로 감압하는 과 정에서 호정화된 쌀이 부피가 팽창하고 다공성 구조가 되어 쉽게 분말화가 가능하다. 쌀의 생전분은 물 분자와 친화력 이 약하여 호화전분과 수화특성의 차이가 있을 뿐만 아니라 효소작용이 어려운데 비하여 호화전분은 규칙적인 분자배 열이 없어 팽창되어 아밀로오스, 아밀로펙틴의 구조에 효 소의 작용이 쉬우며 당화가 잘 되어 산업적으로는 식혜, 막걸리 제조 등에 널리 사용되고 있다 $(18,19)$.

따라서, 본 연구에서는 팽화미분을 원료로 하여 이소말 토올리고당 제조 시 호화처리가 불필요하며 효소 작용이 활발한 것에 착안하여 효소를 혼합하여 1 회 처리만으로 제조가 가능한 One-step 효소 반응을 통해 이소말토올리고 당을 제조하였고, 이때 기질 혼합물의 농도, 반응온도 및 시간 등 처리조건을 달리하여 제조조건별 이소말토올리고 당의 이화학적 품질특성을 확인하였으며, 일반적으로 Two-step(또는 Three-step) 으로 제조되는 시판 이소말토올 리고당의 구성당 분석을 통해 차이점을 확인하였다.

\section{재료 및 방법}

실험 재료

본 실험에 사용한 팽화미는 남원지역에서 재배한 신동진 품종으로 제조한 튀밥제품을 이용하였으며, 이를 가정용분 쇄기(HR2095, PHILIPS, Amsterdam, Netherlands)로 분말화 하여 $50 \mathrm{mesh}$ 표준체에 고르게 내렸다. 준비된 팽화미분 시료는 PE 비닐백에 밀봉하여 냉동고(WSM-1242RF, Woosung INC, Namyangju, Korea)에 보관하며 이소말토올 리고당 제조에 사용하였다.

\section{이소말토올리고당 제조}

팽화미분을 이용한 이소말토올리고당의 제조에 필요한 기질로 사용하였으며, 반응을 촉매하는 효소는 시중에 판 매하는 상업용 효소인 maltogenase L(Novozyme, Copenhagen, Deanmark), Promozyme D2(Novozyme), Transglucosidase(L Amano, Kanagawa, Japan)를 각각 기질의 $0.5 \%(\mathrm{v} / \mathrm{w})$ 사용하 였다. 이때, 제조조건별 생성물의 차이를 확인하기 위하여 기질과 물 혼합액(slurry)의 알파미분 함량 $(15 \%$ 와 $20 \%$, $\mathrm{w} / \mathrm{v})$ 과 효소반응에 필요한 온도 $\left(60^{\circ} \mathrm{C}, 65^{\circ} \mathrm{C}\right)$ 조건을 각각 달리하여 4가지 실험군을 설정하였다(PR15-60, PR20-60, PR15-65, PR20-65). 이후, 시간별로 이소말토올리고당 생 성 정도를 확인하기 위하여 설정한 온도를 유지시켜주며 $0,6,24,48$ 시간동안 반응시켜 채취한 시료를 통해 이화학 적 품질특성을 분석하였다.

\section{환원당 및 $\mathrm{DE}$}

환원당 함량은 DNS 법(21)으로 측정하였다. 즉, 시료액 을 500 배 희석하여 $0.5 \mathrm{~mL}$ 취한 뒤, DNS 시약을 $0.5 \mathrm{~mL}$ 첨가하여 항온수조에서 15 분간 끓여 반응시킨 후 얼음물로 10 분간 급속 냉각하였다. 반응이 끝난 시료의 흡광도를 MicroPlate reader(Tecan, Infinite M200, Mannedorf, Switzerland)를 이용하여 $550 \mathrm{~nm}$ 에서 측정하였으며, 표준 물질로 사용된 포도당의 검량곡선을 작성하기 위해 0.5 , $0.25,0.125 \mathrm{mg} / \mathrm{mL}$ 로 희석하여 회귀방정식을 구한 뒤 값을 계산하였다. $\mathrm{DE}$ (포도당 당량) 측정은 식품공전 시험법(26) 에 따라 이소말토올리고당 제조액을 $105^{\circ} \mathrm{C}$ oven에 넣어 항량이 될 때까지 건조시킨 후 고형분 함량을 구하여 아래 의 식을 통해 나타내었다.

$$
\mathrm{DE}(\%)=\frac{\text { reducing sugar content }(\%)}{\text { solid } \text { content }(\%)} \times 100
$$

\section{가용성 고형분}

팽화미를 이용하여 제조한 이소말토올리고당액의 가용 성고형분 함량은 반응시간별 시료를 일정량 취해 휴대용 굴절 당도계(Hand refractometer, PAL-1, Atago, Minato-ku, 
Japan)를 이용하여 ${ }^{\circ} \mathrm{Brix}$ 로 표시하였고, 모든 분석은 3 회 반복으로 측정한 수치를 평균값으로 나타내었다.

TLC

시간에 따른 시험용액의 변화를 확인하기 위해 Thin Layer Chromatography(TLC)분석을 실행하였다. 제조조건 별 효소처리 반응물을 $0.2 \mu \mathrm{m}$ syringe filter(PVDF Filter, Wahtman, Buckinghamshire, England)를 이용하여 통과시킨 후 TLC Plate(HPTLC silica gel 60 F254)에 점적하여 전개용 매(Nitromethane:1-prophanol: $\mathrm{H}_{2} \mathrm{O}=2: 5: 1.5$ )가 담긴 TLC Chamber $(125 \times 145 \mathrm{~mm})$ 에서 2차 전개하였다. 발색시약으로 는 $10 \%$ sulfuric acid 용액으로 반응시켜 $105^{\circ} \mathrm{C}$ oven에 20 분 간 가열 건조하였으며, 실험에 사용된 모든 시약은 SigmaAldrich 사(St. Louis, MO, USA)의 제품을 이용하였다.

\section{$\mathrm{HPLC}-\mathrm{ELSD}$ 를 이용한 구성당 정량분석}

정량 분석에 사용된 18 종의 표준물질 중 fructose, glucose, sucrose, nigerose, maltose, kojibiose, isomaltose, maltotriose, panose, isomaltotriose, maltoheptaose 는 SigmaAldrich(St. Louis, Mo, USA), maltotetraose, isomaltotetraose, maltopentaose, isomaltopentaose, maltohexaose는 TRC사 (Toronto, Canada)에서 isomaltohexaose, isomaltoheptaose는 Omicron사(Amherst, USA)에서 구입하여 사용하였다. 모든 표준물질로 사용된 시약은 분석용 등급이상을 사용하였으 며, 각각의 18 종 표준물질 $20 \mathrm{mg}$ 을 바이알에 정밀히 달아 $1 \mathrm{~mL}$ 의 증류수에 용해시켜 stock standard solution이 20,000 $\mu \mathrm{g} / \mathrm{mL}$ 가 되게 하였다. 표준용액은 시험용액의 농도를 고려 하여 $500,1,000,2,000 \mu \mathrm{g} / \mathrm{mL}$ 가 되도록 희석하여 검량선을 작성한 후 정량 분석하였다. 이소말토올리고당 함량 비교 분석을 위해 대조구로 사용되어진 시판 올리고당은 유통업 체에서 상온상태에서 판매중인 제품을 구입하여 사용하였 다. 검체는 팽화미분으로 제조한 이소말토올리고당액을 냉 장플로어원심분리기(Himac CR21GII, Hitachi, Tokyo, $\mathrm{Japan})$ 를 이용하여 원심분리 $(11,180 \times \mathrm{g}, 20$ 분 $)$ 한 뒤, 상등액 을 취하여 여과, 정제 후 분석에 사용하였다. 정제 과정은 이온교환수지(Amberlite IR-120, Amberlite IRA-67, Sigma Aldrich)를 유리관 컬럼에 충진 후 통과하여 반응액의 전기 전도도(Almemo 2890-9, Ahlborn, Holzkirchen, Germany) 값 의 감소를 통해 간섭물질의 제거를 확인하였으며, 정제과 정을 거쳐 $0.2 \mu \mathrm{m}$ syringe filter(PVDF Filter, Wahtman, Buckinghamshire, England)로 반복 여과 후 $1 \mathrm{~mL}$ 씩 정밀히 취하여 시험용액을 조제하였다.

정량 분석 조건을 설정하기 위하여 HPLC system(Agilent Technologies 1260 infinity, Palo Alto, CA, USA)과 $\mathrm{ELSD}$ (Palo Alto, CA, USA)를 사용한 분석조건을 Table 1에 나타내었다.
Table 1. HPLC-ELSD analysis conditions of isomaltooligosaccharides manufactured by one-step method with puffed rice flour

\begin{tabular}{|c|c|c|}
\hline $\begin{array}{l}\text { Instrument } \\
\text { Column }\end{array}$ & \multicolumn{2}{|c|}{$\begin{array}{l}\text { Agilent Technologies } 1260 \text { infinity } \\
\text { shodex HILICpak VN-50 4D }\end{array}$} \\
\hline \multirow{10}{*}{ Mobile phase } & \multicolumn{2}{|c|}{ Gradient conditon } \\
\hline & Time table (min) & Acetonitrile (\%) \\
\hline & 0 & 89 \\
\hline & 25 & 89 \\
\hline & 30 & 81 \\
\hline & 40 & 80 \\
\hline & 75 & 75 \\
\hline & 80 & 73 \\
\hline & 80.1 & 89 \\
\hline & 85 & 89 \\
\hline Flow rate & \multicolumn{2}{|c|}{$1.0 \mathrm{~mL} / \mathrm{min}$} \\
\hline Temperature & \multicolumn{2}{|c|}{$65^{\circ} \mathrm{C}$} \\
\hline Injection volume & \multicolumn{2}{|c|}{$10 \mu \mathrm{L}$} \\
\hline \multirow{3}{*}{ Detector } & \multicolumn{2}{|c|}{ ELSD } \\
\hline & Temperature & $90^{\circ} \mathrm{C}$ \\
\hline & Gain & 10 \\
\hline
\end{tabular}

\section{통계처리}

모든 실험의 통계처리는 $12.0 \mathrm{~K} \mathrm{SPSS(Statistical} \mathrm{Package}$ for Social Sciences, SPSS Inc., Chicago, IL, USA) software package 프로그램을 사용하였으며 측정 값은 기술통계분석 으로 평균값과 표준편차를 산출하였다. 시료간의 유의성 검정은 일원배치분산분석(one-way ANOVA)을 실시한 후, Duncan's multiple range test를 실시하여 $p<0.05$ 수준에서 확인하였다.

\section{결과 및 고찰}

환원당

환원당은 glucose, maltose 등의 당류를 총칭하며 반응성 이 있는 알데히드기나 케톤기를 갖고 금속염 알칼리 용액을 환원시키는 성질을 갖는 당을 말한다(22). 반응 0 시간째 실험군별 환원당의 함량은 $5.76-7.77 \%$ 로 기질 혼합물의 농 도 및 반응온도에 따라 모두 유의적인 차이를 보였고 ( $\mathrm{p}<0.05)$, 기질 혼합물의 농도가 $15 \%$ 인 PR $15-60, \mathrm{PR} 15-65$ 실험군의 환원당 함량이 PR20-60, PR20-65 실험군의 환원 당 함량보다 낮은 경향을 보였다. 이는 PR15-60, PR15-65 실험군보다 PR20-60, PR20-65 실험군에 포함된 기질의 양 이 많고 필요한 효소의 양이 충분한 결과로 보이며, Lee와 $\mathrm{Yi}(19)$ 의 연구에서도 알파화된 팽화미분의 첨가량이 증가 할수록 환원당이 높았다는 결과와 일치한다. 반응시간이 
경과함에 따라 환원당 함량은, 반응 1 시간째 7.40-10.62\%, 6시간째 $11.05-15.64 \%, 24$ 시간째 $13.89-21.21 \%$ 로 48시간까 지 지속적으로 증가하였으나 PR15-60, PR20-60 실험군에 서는 큰 차이가 없는 것으로 나타났다(Fig. 1).

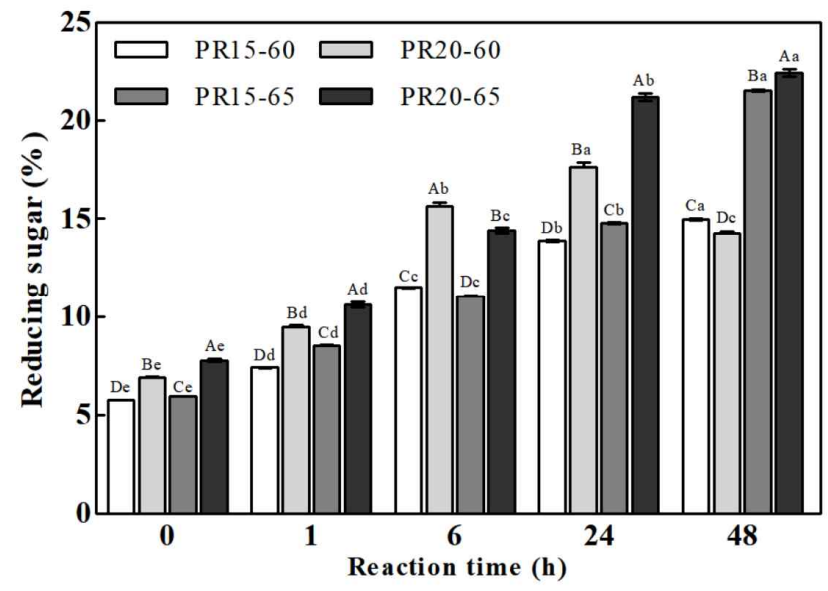

Fig. 1. Reducing sugar of isomaltooligosaccharides manufactured by One-step method with puffed rice flour.

$A-D$, a-d Different letters within the same bar are significantly different from each other (A-D, between experimental group; a-e, between different reaction time) by Duncan's multiple range test $(\mathrm{p}<0.05)$.

\section{Dextrose equivalent (DE)}

$\mathrm{DE}$ 는 전분을 기질로 하여 당화 처리를 하였을 때 당의 분해된 정도를 나타내며 당화 반응시간이 경과함에 환원당 량과 함께 증가한다(23). 팽화미분을 이용하여 One-step 제 조방법으로 제조한 이소말토올리고당의 $\mathrm{DE}$ 값은 제조 조 건별로 0시간째 36.56-41.63\%으로, 기질 혼합물의 농도 및 반응온도별 모두 유의적인 차이를 보였다(p<0.05)(Fig. 2). 이후, 반응시간이 경과함에 따라 환원당 함량은, 반응 1 시

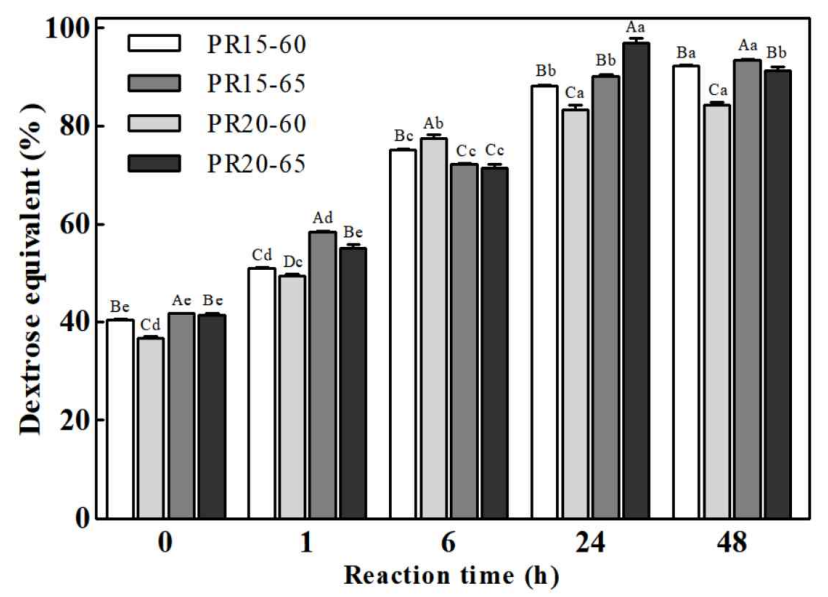

Fig. 2. Dextrose equivalent (DE) of isomaltooligosaccharides manufactured by One-step method with puffed rice flour.

$A-D$, a-d Different letters within the same bar are significantly different from each other (A-D, between experimental group; a-e, between different reaction time) by Duncan's multiple range test $(\mathrm{p}<0.05)$.
간째 $49.44-58.33 \%, 6$ 시간째 $71.55-77.39 \%, 24$ 시간째 83.28-97.00\%로 지속적으로 증가하였으나 48시간째 84.24-93.53\%로 대체적으로 감소하는 경향을 나타냈다. 이 는 반응이 장시간 지속되면서 환원성 말단을 가진 포도당, 맥아당 등 이 전이효소 작용 시 transglucosidse의 수용체 혹은 공여체로 참여하여 총량대비 소폭 감소하는 경향을 나타낸 것으로 보인다.

\section{가용성 고형분}

팽화미분을 이용하여 One-step 제조방법으로 제조한 이 소말토올리고당의 반응 0 시간째 실험군 별 당도는 12.33$15.80{ }^{\circ} \mathrm{Brix}$ 로 기질과 물의 배합비에 따라 유의적인 차이를 보였고, 기질 함량 같은 비율에서 반응온도가 다른 실험군 간 유의적 차이가 없었으며 기질의 함량이 높은 PR20-60, PR20-65의 당도가 더 높았다(Fig. 3). 반응 초기 기질 혼합물 의 농도가 같은 실험군의 유의적 차이가 없었으나 반응 6시간째 PR20-60, PR20-65 실험군을 제외하면 반응 1시간 부터는 모든 실험군별 당도의 유의적인 차이를 보였다. 반 응시간이 증가함에 따라 대체로 모든 실험군의 당도가 증가 하는 경향을 보였으며 반응 48시간째 당도는 14.33-19.70 ${ }^{\circ} \mathrm{Brix}$ 로 PR20-65 실험군이 가장 높았고, 다음으로 PR20-60, PR15-65, PR15-60 순으로 나타났다. PR20-60, PR20-65 실 험군이 유의적으로 높은 당도를 보이는 것은( $\mathrm{p}<0.05)$ 기질 인 팽화미분에 효소가 작용하여 가수분해된 결과 당도가 증가한 것(25)과 같은 맥락으로 기질혼합물의 농도가 $20 \%$ 인 PR20-60, PR20-65 실험군의 기질 함량이 더 높으며, 이 때 필요한 효소의 농도가 충분하기 때문인 것으로 보인다.

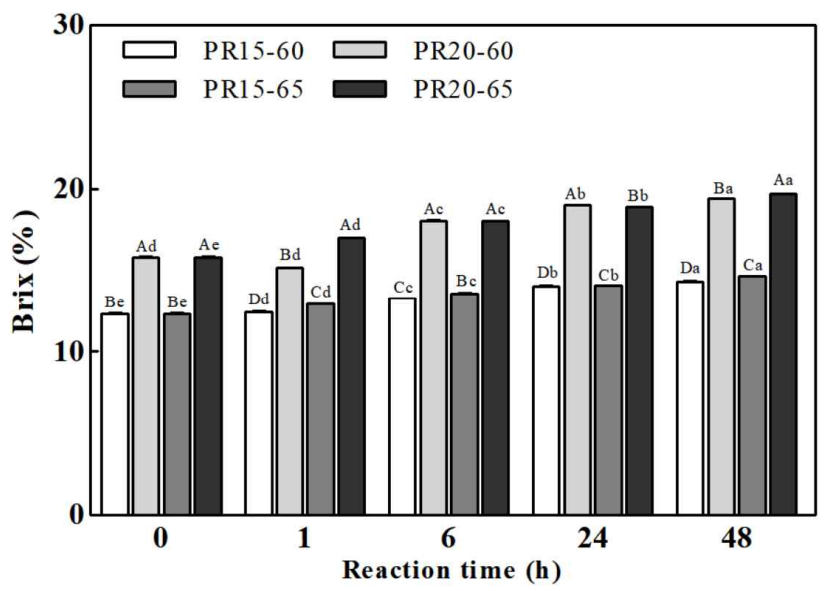

Fig. 3. Total soluble solids of isomaltooligosaccharides manufactured by One-step method with puffed rice flour.

$A-D$, a-d Different letters within the same bar are significantly different from each other (A-D, between experimental group; a-e, between different reaction time) by Duncan's multiple range test $(\mathrm{p}<0.05)$.

TLC

팽화미분을 이용하여 One-step 제조방법으로 제조한 이 
소말토올리고당의 구성당 및 올리고당 생성여부를 확인하 기 위해 TLC로 분리하였으며, 기질 혼합물의 농도 및 반응 온도, 반응시간 $(0,1,6,12,24,48$ 시간)에 따른 포도당, 맥아 당 및 그 이상 중합도를 가진 당의 생성여부를 확인하였다. Fig. 4 와 같이 각 실험군 사진의 제일 왼쪽열에 $0.1 \%$ 농도의 표준용액을 통해 표시된 포도당, 과당, 자당, 맥아당의 위치 를 확인했고, 0 시간부터 48 시간까지 반응액을 표시된 순서 와 같이 점적하여 생성된 당이 분리된 결과, 반응시간별 포도당 위치의 점의 크기가 크고 진해지는 것을 통해 반응 시간이 경과함에 따라 포도당이 많이 생성된 것을 확인하였 다. 모든 실험군이 반응 6 시간째부터 표준물질의 분자량보 다 중합도가 큰 생성물이 진하게 표시되어 나타나는 것을 확인하였고, 기질의 함량이 높은 PR20-60, PR20-65 실험군 이 PR15-60, PR15-65 실험군 보다 상대적으로 더 진하게 나타났다. 반응온도별로는 반응온도가 높은 PR15-65, PR20-65 실험군에서 더 spot이 진하게 확인되는 것으로 보아 포도당 및 올리고당의 함량이 더 높은 것으로 판단되 며, 이는 앞서 제시한 환원당, $\mathrm{DE}$ 및 가용성고형분 분석 결과와 일치하는 경향을 띄었다.
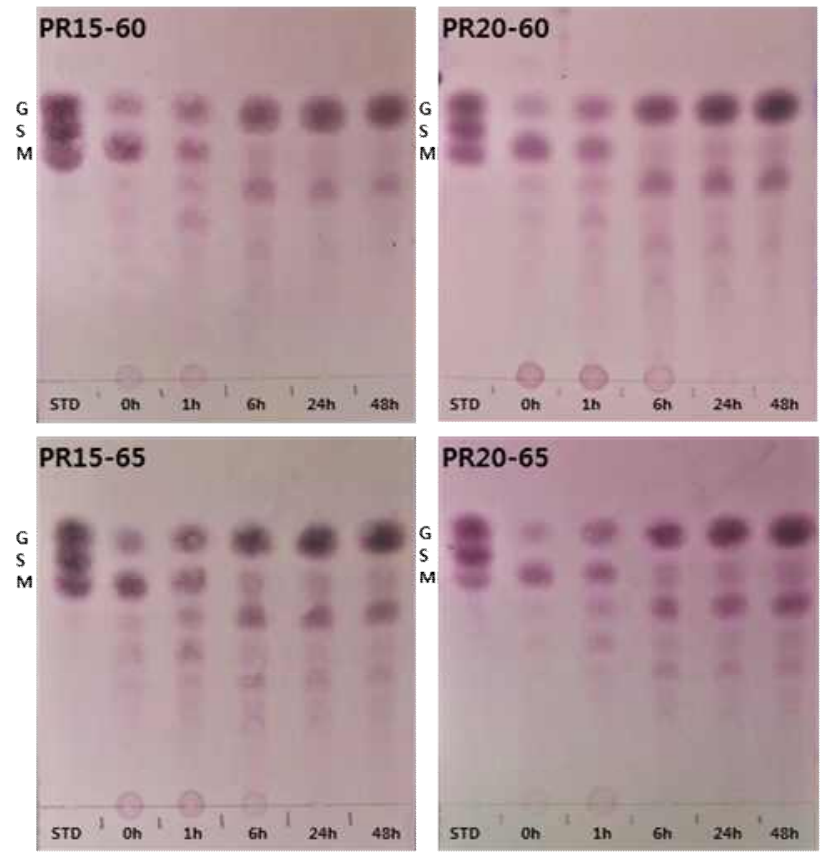

Fig. 4. TLC analysis in experiment groups of enzyme-substrates reaction product.

\section{HPLC}

팽화미분을 이용하여 One-step 제조법으로 제조 시 제조 조건별 생성물의 구성당 및 함량의 정량·정성 분석 결과 동일 반응시간 샘플에서 PR20-65 실험군의 구성당 및 이소 말토올리고당 함량이 최대로 확인되었으며(data not shown), 이러한 PR20-65 실험군의 반응시간별 생성물의 변화를 관 찰하기 위해 반응 0 시간부터 $1,6,24,48$ 시간 동안 반응물의
분석결과를 Table 2에 나타내었다. 확인된 이소말토올리고 당은 nigerose, isomaltose, panose, isomaltotriose, isomaltotetraose, isomaltopentaose, isomaltohexaose, isomaltoheptaose로, 이 외에도 glucose, maltose, imaltotriose, maltotetraose, maltopentaose가 함께 검출되었다. PR20-65 실험군에 포함 된 총 당류의 함량은 반응시간이 경과함에 따라 $0,1,6$ 시간째, 각각 $202.63 \mathrm{mg} / \mathrm{mL}, 207.87 \mathrm{mg} / \mathrm{mL}, 219 \mathrm{mg} / \mathrm{mL}$ 로 증가하였으나, 이 후 24시간, 48 시간째에는 각각 170.36 $\mathrm{mg} / \mathrm{mL}, 122.22 \mathrm{mg} / \mathrm{mL}$ 으로 감소하였다. 총당 중 이소말토 올리고당의 함량 및 비율은 0시간 $(24.54 \mathrm{mg} / \mathrm{mL}, 14.12 \%)$, 1시간 $(56.40 \mathrm{mg} / \mathrm{mL}, \quad 34.31 \%), \quad 6$ 시간 $(135.00 \mathrm{mg} / \mathrm{mL}$, $66.11 \%), 24$ 시간(115.48 mg/mL, 68.04\%), 48시간(76.07 $\mathrm{mg} / \mathrm{mL}, 63.28 \%$ )으로 총이소말토올리고당 함량은 반응 6시 간째에 최대치를 보였고, 총당 대비 이소말토올리고당 함 량비율은 반응 24시간째 최대 함량비를 차지하는 것으로 확인되었다. 반응 6시간의 경우 isomaltose가 약 66.40 $\mathrm{mg} / \mathrm{mL}$ 로 가장 높은 수준으로 검출되었고 isomaltotriose (23.15 $\mathrm{mg} / \mathrm{mL})$, panose $(21.10 \mathrm{mg} / \mathrm{mL})$, isomaltotetraose $(11.45 \mathrm{mg} / \mathrm{mL})$ 순으로 검출되었으며, isomaltopentaose, isomaltohexaose, isomaltoheptaose는 미량 검출되었다. 이는 기존 연구결과와 같이 이소말토올리고당을 함유한 올리고 당에 isomaltose와 panose가 가장 많이 함유하고 있다는 결 과 $(24,25)$ 와 일치하였으며 반응 1 시간째부터 포도당이 분 지결합으로 4개 결합된 isomaltotetraose가, 반응 6시간째부 터 5 개 이상 결합된 isomaltopentaose, isomaltohexaose 등이 검출되었다.

\section{제조 방법에 따른 구성당 및 함량 분석}

알파미분을 이용하여 One-step 방법으로 제조한 이소말 토올리고당이 기존 방식으로 제조되는 이소말토올리고당 제품과의 품질 차이를 비교하기 위하여 시중에서 유통중인 Two-step 방법으로 제조한 이소말토올리고당(대한민국 공 개특허 제 10-2012-0045298호) 제품을 대조군으로 하여 각 각의 이소말토올리고당 구성당 및 함량분석을 실시하였으 며 이를 Table 3에 나타내었다. One-step 방법으로 제조한 이소말토올리고당의 경우 glucose가 $19.6 \%$ 이었으며 maltose 및 중합도 3 이상의 올리고당이 미량 검출 되었고 그 외 중합도 2 이상의 가지결합 $(\mathrm{a}-1,6)$ 형태의 이소말토올리고당 함량이 약 $70 \%$ 이상으로 검출되었다. Two-step 방식으로 제조한 시판 이소말토올리고당 제품의 경우 glucose가 $26.3 \%$ 이었으며 maltose는 $8.7 \%$, 중합도 3 이상의 올리고당 이 $13.8 \%$, 그리고 중합도 2 이상의 가지결합(a-1,6) 형태의 이소말토올리고당 함량이 $51 \%$ 로 나타났다. 비록 대조구로 선택한 시판 올리고당의 제조에 사용한 효소조합과 반응조 건이 상이한 까닭에 절대적인 품질비교는 어려우나 One-step 방식으로 제조한 이소말토올리고당의 포도당 함 량이 낮을 뿐만아니라, 이소말토올리고당이 약 $20 \%$ 더 포 함된 것을 확인 할 수 있었다. 
Table 2. Sugar compositions and contents of isomaltooligosaccharides manufactured by one-step method with puffed rice flour

\begin{tabular}{|c|c|c|c|c|c|c|}
\hline & \multirow{2}{*}{ Standard } & \multicolumn{5}{|c|}{ Reaction time (h) } \\
\hline & & 0 & 1 & 6 & 24 & 48 \\
\hline \multirow{2}{*}{ DP1 } & Fructose & - & - & - & - & - \\
\hline & Glucose & $23.83 \pm 0.67^{1)}$ & $24.36 \pm 0.19$ & $26.94 \pm 0.21$ & $29.92 \pm 0.99$ & $27.12 \pm 0.30$ \\
\hline \multirow{5}{*}{ DP2 } & Sucrose & $4.45 \pm 0.11$ & - & - & - & - \\
\hline & Nigerose & - & - & $6.59 \pm 0.01$ & $8.49 \pm 0.90$ & $6.74 \pm 0.15$ \\
\hline & Maltose & $118.99 \pm 1.48$ & $101.07 \pm 0.66$ & $29.74 \pm 0.17$ & $6.37 \pm 0.95$ & - \\
\hline & Kojibiose & - & - & - & $8.14 \pm 3.06$ & $6.11 \pm 0.07$ \\
\hline & Isomaltose & $4.82 \pm 0.28$ & $18.29 \pm 0.61$ & $66.40 \pm 6.29$ & $57.67 \pm 3.37$ & $39.73 \pm 0.18$ \\
\hline \multirow{3}{*}{ DP3 } & Maltotriose & $15.76 \pm 0.01$ & $2.64 \pm 0.05$ & $8.57 \pm 0.04$ & $5.82 \pm 10.30$ & $2.97 \pm 0.04$ \\
\hline & Panose & $17.14 \pm 1.63$ & $30.00 \pm 1.35$ & $21.10 \pm 0.22$ & $9.00 \pm 0.78$ & $3.54 \pm 0.43$ \\
\hline & Isomaltotriose & $2.58 \pm 0.02$ & $7.43 \pm 0.04$ & $23.15 \pm 0.30$ & $20.73 \pm 0.52$ & $13.26 \pm 0.59$ \\
\hline \multirow{2}{*}{ DP4 } & Maltotetraose & $8.95 \pm 0.61$ & $13.76 \pm 0.06$ & $9.79 \pm 0.11$ & $4.01 \pm 1.01$ & $3.32 \pm 0.00$ \\
\hline & Isomaltotetraose & - & $1.27 \pm 0.03$ & $11.45 \pm 0.25$ & $5.71 \pm 0.90$ & $3.37 \pm 0.01$ \\
\hline \multirow{2}{*}{ DP5 } & Maltopentaose & $6.10 \pm 0.27$ & $9.06 \pm 0.10$ & $4.80 \pm 0.28$ & $3.80 \pm 0.53$ & $4.62 \pm 0.09$ \\
\hline & Isomaltopentaose & - & - & $3.24 \pm 0.56$ & $2.92 \pm 1.70$ & $2.98 \pm 0.37$ \\
\hline \multirow{2}{*}{ DP6 } & Maltohexaose & - & - & $4.54 \pm 0.01$ & $4.96 \pm 0.67$ & $4.76 \pm 0.68$ \\
\hline & Isomaltohexaose & - & - & $2.80 \pm 0.19$ & $3.69 \pm 0.87$ & $2.29 \pm 0.01$ \\
\hline \multirow{4}{*}{ DP7 } & Maltoheptaose & - & - & - & - & - \\
\hline & Isomaltoheptaose & - & - & $3.75 \pm 0.14$ & $4.20 \pm 0.06$ & $4.97 \pm 0.36$ \\
\hline & Isomalto-oligosaccharides & $24.54 \pm 3.93$ & $56.40 \pm 1.16$ & $138.47 \pm 7.06$ & $118.92 \pm 1.54$ & $76.88 \pm 0.38$ \\
\hline & Total sugar & $202.63 \pm 5.30$ & $207.87 \pm 1.51$ & $222.85 \pm 6.92$ & $175.43 \pm 20.64$ & $125.78 \pm 1.48$ \\
\hline
\end{tabular}

${ }^{1)}$ Mean value of array \pm SD.

Table 3. Sugar compositions of isomaltooligosaccharides manufactured by one-step and two-step method

\begin{tabular}{ccccccc}
\hline & \multicolumn{5}{c}{ Composition sugar (\%) } \\
\cline { 2 - 7 } Production method & Fructose & Glucose & Sucrose & Maltose & $\begin{array}{c}\text { Malto-oligo saccharides } \\
\text { (DP3-) }\end{array}$ & $\begin{array}{c}\text { Isomalto-oligo saccharides } \\
\text { (IMO, Branched }\end{array}$ \\
& - & 19.6 & - & 0.5 & 5.3 & 75.0 \\
\hline One-step IMO) & - & 26.3 & - & 8.7 & 13.8 & 51.0 \\
Two-step IMO & & - & &
\end{tabular}

${ }^{1)}$ Experimental isomaltooligosaccharides.

${ }^{2)}$ Commercial isomaltooligosaccharides.

\section{요 약}

본 연구는 이소말토올리고당 제조에 필요한 액화-당화전이 반응을 One-step 방법으로 확립하기 위하여 팽화미분 을 이용하여 제조조건별 이화학적 품질특성(환원당, $\mathrm{DE}$, 가용성고형분, 당 구성 및 함량)을 확인하였다. 기질과 물의 비율 그리고 반응온도를 각각 달리한 4가지 실험군 (PR15-60, PR20-60, PR15-65, PR20-65)에 상업용 효소인 maltogenase L, Promozyme D2, Transglucosidase를 처리하 여 이소말토올리고당을 제조하였다. 실험 결과, 환원당 함 량은 반응 0시간째 기질 혼합물에 따라 실험군별 유의적인
차이를 보였고 반응시간이 경과함에 따라 함량이 지속적으 로 증가하였다. 그러나 반응온도가 다른 $60^{\circ} \mathrm{C}$ 와 $65^{\circ} \mathrm{C}$ 각각 의 실험군에서 유의적 차이를 나타냈다. $\mathrm{DE}$ 는 모든 실험군 에서 반응시간에 따라 선형적으로 증가하였으나 48시간에 서 Transglucosidse 전이 효소 작용으로 대체적으로 소폭 감소하는 경향을 보였다. 가용성고형분은 반응 1시간부터 유의한 차이를 보여 PR20-65 실험군이 반응 48시간째 19.70 ${ }^{\circ} \mathrm{Brix}$ 로 가장 높았고 PR20-60, PR15-65, PR15-60 순으로 나타났다. TLC 분석결과, 모든 실험군에서 반응 6시간부터 중합도가 큰 생성물이 진하게 표시되었으며 반응온도가 높고 기질함량이 많은 PR20-65에서 다른 실험군보다 spot 
이 더 진하게 나타나는 것을 확인하였다. HPLC 분석에서 는 PR20-65 실험군의 6시간 반응에서 구성당 $(219 \mathrm{mg} / \mathrm{mL})$ 및 이소말토올리고당 함량 $(135.00 \mathrm{mg} / \mathrm{mL})$ 이 최대로 확인 되었다. 이상의 결과를 종합하여 볼 때, 팽화미분을 이용하 여 One-step 이소말토올리고당 제조 시 기질혼합물의 고형 분 함량 $20 \%(\mathrm{w} / \mathrm{v}), 65^{\circ} \mathrm{C}$ 의 조건에서, 6시간 처리 시 135.00 $\mathrm{mg} / \mathrm{mL}$ 로 가장 많은 함량의 이소말토올리고당이 생성되는 것으로 확인되었다. 또한 One-step 방식으로 제조 시, 기존 의 Two-step 방식으로 제조한 이소말토올리고당 보다 포도 당 함량이 낮을 뿐만 아니라 가지결합을 한 이소말토올리고 당이 약 $20 \%$ 더 생성됨을 확인하였다. 이는 식품 조리 및 가공용으로도 다양하게 사용되는 이소말토올리고당의 제 조 공정을 단축하고 건강기능성 효능이 확인된 이소말토올 리고당의 함량이 증진된 제조방법을 개발함으로써 쌀 소비 촉진에 긍정적인 영향을 줄 수 있을 것으로 사료된다.

\section{감사의 글}

본 연구는 농촌진흥청 공동연구사업(과제번호: PJ013126) 의 지원에 의해 이루어진 것으로써 이에 감사드립니다.

\section{References}

1. Ahn JW, Hong SS, Park KW, Seo JH (1996) Reaction mode of transglucosidase from Aspergillus niger for production of isomaltooligosaccharides. J Korean Food Sci Technol, 28, 273-278

2. KFDA (2012) Korea food code I . Korea Food \& Drug Administration, Seoul, Korea, p 65-66

3. Nunokawa Y (1981) Oligosaccharides in sake. J Jpn Soc Starch Sci, 28, 109-117

4. Nishino R, Ozawa Y, Yasuda A, Sakasai T (1981) Oligosaccharides in soy souce. J Jpn Soc Starch Sci, 28, 125-131

5. Ann YG (1997) A study on sugars in Korean sweet rice drink 'Sikhye'(I): Sugar content and its composition. Korean J Food Nutr, 10, 82-86

6. Takanobu K, Fukui F, Takaku H, Machida Y, Arai M, Mitsuoka T (1988) Effect of isomalto-oligosaccharides on human fecal flora. Bifidobact Microflora, 7, 61-69

7. Kanno T (1990) Some functional properties of so-called isomalto-oligosaccharides and their applications to food industry. J Jpn Soc Starch Sci, 37, 87-97

8. Hamada S, Koga T, Fujiwara T, Ooshima T (1984) Role of oligosaccharides in dental caries development. J Jpn
Soc Starch Sci, 31, 83-91

9. Delzenne NM, Roberfroid MR (1994) Physiological effects of non-digestible oligosaccharides. Lebensm Wiss Technol, 27, 1-6

10. Mizubuchi H, Yajima T, Aoi N, Tomita T, Yoshikai Y (2005) Isomalto-oligosaccharides polarize Th1-like responses in intestinal and systemic immunity in mice. J Nutr, 135, 2857-2861

11. Yen CH, Tseng YH, Kuo YW, Lee MC, Chen HL (2011) Long-term supplementation of isomalto-oligosaccharides improved colonic microflora profile, bowel function, and blood cholesterol levels in constipated elderly people: A placebo-controlled, diet-controlled trial. Nutr, 27, 445-450

12. Kim JR, Yook C, Kwon HK, Hong SY, Park CK, Park KH (1995) Physical and physiological properties of isomaltooligosaccharides and fructooligosaccharides. Korean J Food Sci Technol, 27, 170-175

13. Kim MJ, Chun JY, Choi KS (2016) Physicochemical property and starch digestibility of Tarakjuk prepared with enzyme treated rice extrudate powder. Korean J Food Nutr, 29, 692-697

14. Kaneko T, Kohmoto T, Kikuchi H, Shiota M, Iino H, Mitsuoka T (1994) Effects of Isomaltooligosaccharides with different degrees of polymerization on human fecal bifidobactcria. Biosci Biotechnol Biochem, 58, 2288-2290

15. Ahn JW, Park KW, Seo JH (1998) Continuous production of isomaltooligosaccharides by immobilized transglucosidase in a packed-bed reactor. Korean J Food Sci Technol, 30, 110-117

16. KOSIS (2015) Statistical Annual Report (2009/2010). Korean Statistical Information Service, Daejeon, Korea

17. Oh B, Yi YH (2016) Physicochemical properties of rice powder and puffed rice powder ice cream with a-amylase. Food Eng Prog, 20, 1-7

18. Lee MW, Yi YH (2012) Quality characteristics of Sikhye prepared with puffed rice powder during saccharification. Korean J Food Sci Technol, 44, 553-558

19. Kim JY, Sung KW, Bae HW, Yi YH (2007) pH, acidity, color, reducing sugar, total sugar, alcohol and organoleptic characteristics of puffed rice powder added Takju during fermentation. Korean J Food Sci Technol, 39, 266-271

20. Dubois M, Gilles KA, Hamilton JK, Rebers PA, Smith F (1956) Colorimetric method for determination of sugars and related substances. Anal Chem, 28, 350-358

21. Lee HS, Kwon KH, Kim BS, Kim JH (2009) Quality characteristics of instant Nuroong-gi to which Dioscorea 
japonica powder was added. Korean J Food Preserv, 16, 680-685

22. Lee JE, Choi YH, Cho MG, Park SY, Kim EM (2012) Characteristics of Jochung by wet-milled rice flour and steamed rice. Korean J Food Nutr, 25, 637-643

23. Dahlqvist A, Auricchio S, Semenza G, Prader A (1963) Human intestinal disaccharidases and hereditary disaccharide intolerance. The hydrolysis of sucrose, isomaltose, palatinose (isomaltulose), and a 1,6- $a$ -oligosaccharide (isomalto-oligosaccharide) preparation. J Clin Invest, 42, 556-562

24. Hu Y, Ketabi A, Buchko A, Ganzle MG (2013) Metabolism of isomalto oligosaccharides by Lactobacillus reuteri and bifidobacteria. Lett Appl Microbiol, 57, 108-114

25. KFDA (2007) Food code. Korea Food and Drug Administration. Munyoungsa, Seoul, Korea, p 55-57 